Sanrachna

\title{
Agriculture is a Cause of Sub-Optimal Measurement in National Accounts Statistics
}

Kiran Yadav

\begin{abstract}
This paper examines the selected domain of agricultural statistics in India, and how it causes the sub-optimal measurements in national accounts statistics. The agriculture sector has a major role in GDP and also provides more than half of the total workforce their livelihood. Many of the state economies depend on agricultural-based activities. Hence, it is crucial to check the reliability of agricultural statistics and its correct measurement in national accounts for the correct valuation of the economy. The paper discusses the evolution of National Accounts Statistics in India and its embedment with the agriculture sector. The paper further discusses the statistics related to the land use and yield of crops and, - the method and sources used to collect this data. It also discusses the gap of checking the agricultural database and the challenges in the methodology used to estimate the sector contribution in national accounts.
\end{abstract}

Keywords - NAS, National Income, GDP, Agricultural Statistics, Livestock, Crops,

\section{Introduction}

India has been an agrarian economy since its Independence. The Indian economy has been dependent upon the primary sector. The agriculture sector has a lifeline of the economy. In 1950-51, the agriculture sector contributes $51.88 \%$ in GDP. Despite the greatest contributor in GDP in the post-Independence era, the share of agriculture sector in GDP has been declining consistently. The below figure shows that the agriculture sector contribution to the total GDP of India is shrinking, and currently, its contribution is the lowest among the three sectors.

Figure 1: The Percentage share of Agriculture and Allied Sector to Total GDP at Constant 2004-05 Price 


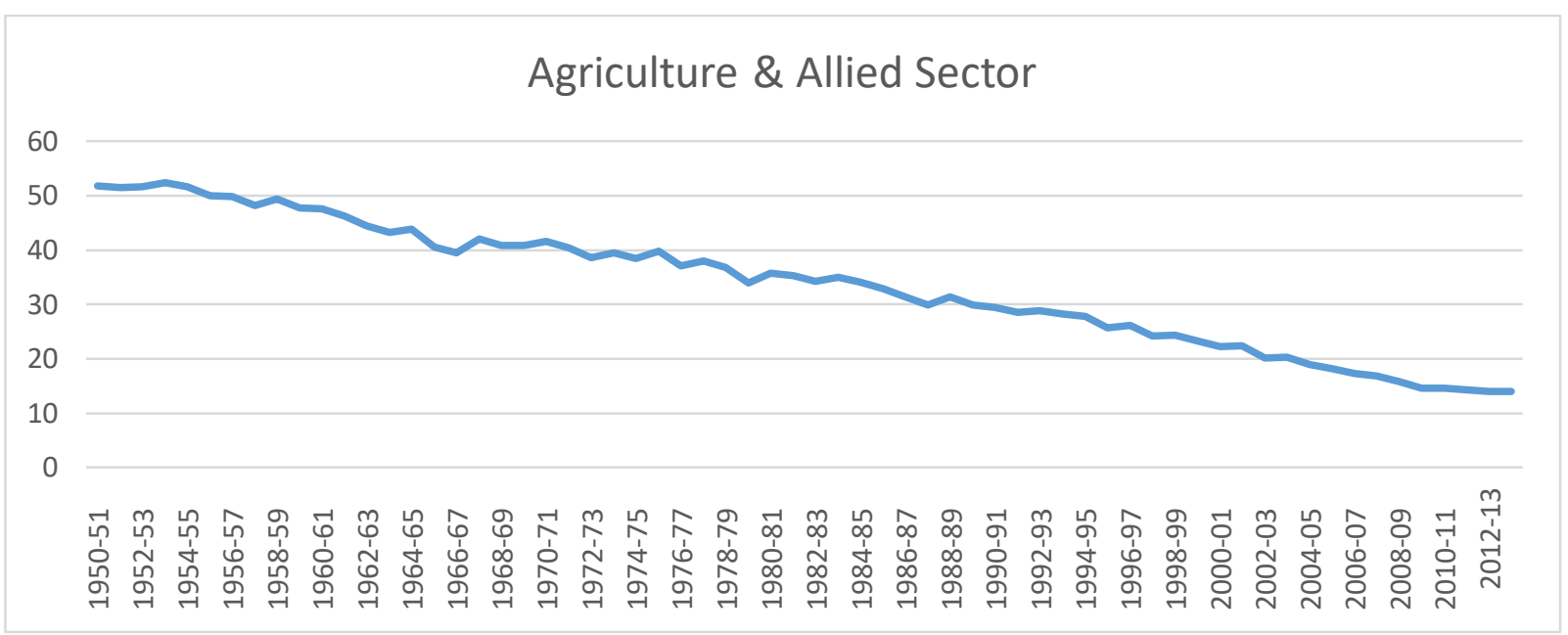

Source: NITI Aayog, 2019

Despite this declining trend, there are many states which depend on agriculture-based activity for their economy. The agriculture sector has also played a major role in employing people, especially from rural areas. They depend on agriculture for their livelihood. It employs $59 \%$ of India's total workforce. Over 70\% of the rural household employ in agriculture in 2016 (Economic Survey, 2019-20). Thus, to get a clear picture of the measurement of agriculture in national income, it becomes important to look at its methodology and statistics in national income. As there are many gaps and loopholes in our statistics, also dataset in India is not uniform and even. Agriculture stills called the backbone of the Indian economy so it becomes necessary to collect and maintain the agriculture statistics in a systematic manner. In order to understand the measurement of the agriculture sector, its gap, and methodological error in national income, it is important to know about the National Accounts Statistics (NAS). This paper, hence, will look into NAS, its measurement, how agriculture and livestock sector embedded in it, and finally the data gap in agriculture statistics and its methodology. To understand the whole mechanism, first, we should know about NAS.

\section{National Accounts Statistics in India}

The nation's income is important in measuring the development of any country. Hence, postIndependence, the need for providing the estimates of national income and other related aggregates were seriously felt. For policy and planning purposes, the National Income Committee was set up by the Government of India in 1949 under the chairmanship of Prof. P.C. Mahalanobis. The Committee was set up to make recommendations regarding the 
compilation of estimation of national income, improving the statistical data, and to promote the research in the field of national income. The Government of India, accepting the recommendation by Committee, transferred the work of estimation of national income to the Central Statistical Organisation (CSO) where a full-fledged separate division was set up which now known as National Accounts Division. (Government of India, 2012)

The National Accounts Statistics (NAS) data is compiled by the CSO of the Ministry of Statistics and Programme Implementation (MOSPI). For the state-level data, State Directorates of Economics and Statistics (DESs) is responsible for compiling the State Domestic Product and other aggregates. To examine the growth of the economy in real terms the aggregates are measured at prices of the selected year called the base year. The first official estimate of national income was prepared with the base year 1948-49. These estimates along with accounts of Public Authorities published as Estimates of National Income in 1956. As the availability of data was improved over the years, the methodology for national income estimates reviewed, and the coverage of estimates extended to many macro-economic aggregates, the title of the publication changed to the present title of National Accounts Statistics (NAS) in 1975.

However, to keep an account of the structural changes that an economy is going through and to represent the real picture of the major macro-economic aggregates, it was felt that to revise the base year. Here are the changes in the base year in chronological order, in August 1967, the base year revised to 1960-61 from 1948-49; in January 1978, it revised to 1970-71; in February 1988, it revised to 1980-81; in February 1999, the base year revised to 1993-94; in January 2006, it revised to 1999-2000; in January 2010, it further revised to 2004-05 and the latest one in January 2015, it revised to 20011-12 ${ }^{1}$. Till the time of 1980-81, the base year was revised to a year which ends with 1 as the estimates on the workforce were obtained from the population census which conducted decennially in the year that ends with 1. However, in 1993-94, the NSSO surveys were used for workforce estimates, which are conducted every five years and considered better than the population census. (Government of India, 2015).

\footnotetext{
${ }^{1}$ After the 2004-05 series, the Employment and Unemployment Survey (EUS) of NSSO was also conducted in 2009-10. But it was not considered as a normal year due to the global slowdown of 2008, and therefore a new EUS was conducted in 2011-12 on which the new base year is revised
} 
Sanrachna

\subsection{Macro-Economic Aggregates and Methodology in NAS}

Preparing the NAS is important as it is the major source of all macroeconomics data in India. It helps us to understand how various transactions from the stage of production of goods and services to the stage of their final allocation are inter-related. It also gives us an insight that how is an economy is running in the country. The data from NAS are used in making macroeconomic models for forecasting the long and short term expectations of the future economy. The NAS is mainly used to evaluate the economy's performance over time. The main primary macro-economic aggregate of national accounts is Gross Domestic Product (GDP) which is the value of goods and services in monetary terms in a given time in the economy. It is also used in estimating many important factors of the economy such as saving rate, capital formation, fiscal deficit, current account deficit, interest payment, the expenditure of social sectors.

To get an idea of NAS, the concept of major macro-economic aggregates becomes important to understand. The major component in NAS is the national income. The national income is the sum of all incomes arising out of economic activity in the country. The measurements of national income can be done in three ways: (a) production or value added method, (b) income generation method, and (c) final utilization method. The production method involves the value added of each sector derived from subtracting the value of input from the total value of output

Gross Value Added (GVA) at factor cost $=$ Value of output - intermediate consumption While the income generation method talks about the income generated through the process of production

GDP at market price $=$ Compensation of employees + Operating surplus $/$ mixed income + Consumption of Fixed Capital $(C F C)+$ Net Indirect Taxes on production and export/import

The final utilization method talks about the income spent on expenditure by various sections such as household consumption expenditure, government consumption expenditure, and capital formation.

$$
\text { GDP at market price }=\text { Final consumption expenditures }+ \text { Gross Fixed Capital }
$$

Formation+Acquisition less disposable of valuables+Change in inventories + Net export of goods and services

National income estimated using the income and product method measures the domestic product at factor cost whereas the national income from the final utilization method gives the 
expenditure at market price. The factor cost is the cost paid to factors of production, on the other hand, market price as the name suggests is the actual price which consumers or producers pay for either purchase of goods or investment purposes. Unlike factor cost, market price includes the impact of subsidies and indirect taxes. National income generally measured at prevailing prices of the current year in the economy or can say current prices. However, estimated over many years, the national income implicitly affected by the price change or inflation. Hence, to avoid the effect of inflation and to provide the growth of the economy in real terms, the national income calculated at a given price of one particular base year called national income at a constant price. The aggregates data, both at the current price and the constant price is published annually by CSO.

As to know the contribution of a particular sector in national income, GVA is considered as a better method. As stated earlier, GVA is expressed as the difference between the value of products, by-products and ancillary activities at prices received by the producers and the value of inputs of raw materials and services consumed in the process of production at purchaser's price. GDP is expressed as the summation of GVA.

Gross Domestic Product (GDP) at factor cost $=$ Sum of GVA at factor cost The GVA represents the contribution of a single agent of the industry or sector to national income. It is considered a better method as it provides the value of goods and service at each stage after subtracting the cost and raw materials used in the production. The usage of GVA is important because, from an economic perspective, it shows the supply side of the economy and can be described as the main entry in the income side of the national accounts balance sheet.

The other important aggregate is Gross Capital Formation (GCF) which refers to the aggregate of gross additions to fixed assets and change in stocks. In NAS, the GCF is estimated by the industry of use, and by type of assets. The GCF by type of assets are derived through commodity flow approach whereas, GCF by the industry of use is derived from the expenditure approach.

$$
G C F=\text { Gross Fixed Capital Formation }(G F C F)+\text { Change in Stocks }(C I S)
$$

\subsection{Publication of NAS and its release time}


Sanrachna

From time to time CSO makes an advance and revised estimates of these estimates to modify it and present it accurately. The various estimates of GDP and other related aggregates for a particular reference period are released at a separate point of time to revise it. The first estimates of annual national income released 2 months before the closing of the reference year which is known as Advance Estimates (AE). These estimates are further revised and released as an update of the advance estimates and present at both current prices and constant price. The other estimates of aggregates are released in January or February of the following year with a 10month lag called Quick Estimates (QE), - along with this, the estimates for the previous year are also get revised and released simultaneously. The estimates of macro-economic aggregates released at both factor cost and market prices while the Domestic Products present the data on GDP and NDP by sector of the origin or by economic activity such as agriculture and allied sector, registered and unregistered manufacturing and so on.

The publication of NAS comes under five parts: Macro-economic Aggregates; Domestic Product; Consumption, saving and capital formation; Public Sector Transactions; and Disaggregated Statements. Besides this, the NAS releases the data on four consolidated accounts: GDP and expenditure, National Disposable Income and its appropriation, Capital Finance, and External Transaction and in addition to this, Input Output Transaction Table (IOTT). These data are accumulated through different primary sources such as through public administrative services, census, and sample surveys conducted by official agencies of state and central government. However, the regional diversities in public administrations responsible for collecting and maintenance of data create the issue of reliability which gives the space for errors. In the case of agriculture, to know how these errors are incorporated, we first need to know how agricultural data is collected.

\section{Statistics of Agriculture and its source}

For collecting and compiling agricultural statistics, India has a two-tier system: at the state level - State Agricultural Statistics Authorities (SASAs) and at the centre level - Directorate of Economics and Statistics, Ministry of Agriculture (DESAg). These two bodies are the pivotal agencies for collecting and compiling agricultural data at pan India level. It publishes all the data in "Agricultural Statistics at a Glance" series. The Directorate of Economics and Statistics (DES) is responsible for the data of estimates of area, production and yield of almost $80 \%$ of 
Sanrachna

crops. The production of crops is estimated through the multiplication of area estimates by corresponding yield estimates. The other agencies are the National Sample Survey Organisation (NSSO) and State Directorate of Economics and Statistics (DESs). These authorities are responsible for providing data for a wide range such as land use, land holdings, crop area, crop production, irrigation, livestock, fishery, forestry, etc. (Government of India)

The land use statistics (LUS) is collected based on three categories. The first category mention as "temporarily settled states". Under this category, the data is compiled from the village land records maintained by revenue agencies or patwari. The data is collected through a system of Timely Reporting Scheme (TRS) under which $20 \%$ of villages are randomly selected for area estimates. Under the second category, which is referred as "permanently settled states", the data is collected through sample surveys in a large sample of $20 \%$ villages/ investigator zones under Establishment of an Agency for Reporting of Agricultural Statistics (EARAS) scheme. The third category covers those states and union territories where there were no agencies for reporting the data. The village headman is responsible for providing the land data - based on their knowledge and experience. The States and UTs covered under these three categories are shown in table 1 in the appendix (Government of India, 2018). The land use data is collected under nine categories: a) Forests, b) Area under non-agricultural use, c) Barren and uncultured land, d) Permanent Pastures and other grazing lands, e) Land under miscellaneous tree crops and groves, f) Culturable wasteland, g) Fallow lands other than current fallows, h) Current fallows, i) Net area sown. To provide details and information on land development programmes these nine categories are further expanding to 22 categories.

Figure 2: All India Foodgrains Area (Million Hectares) from 1950-51 to 2016-17 
Sanrachna

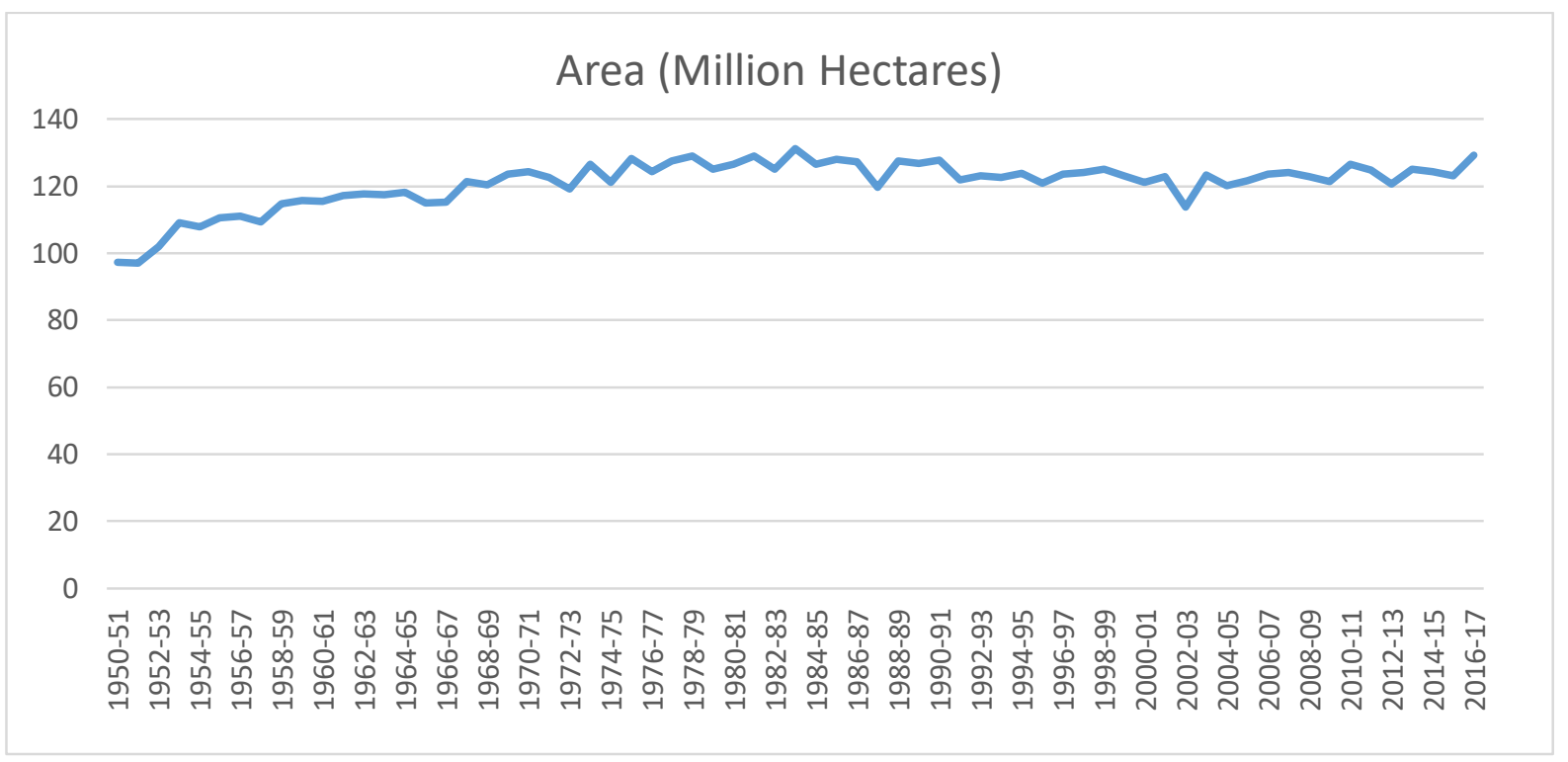

Source: Agricultural Statistics at a Glance 2018

The estimates for yield are collected through Crop Cutting Experiments (CCE) initiated under General Crop Estimation Survey (GCES). Currently, 95\% of crop production is estimated through yield estimates obtained by CCE. The Field Operations Division (FOD) of NSSO, provides training and technical guidance to States and Union territories for properly conducting CCE for better yield estimates. The CCE process involves many steps, starting from the random selection of a field followed by identification and marking of experimental plots, harvesting the crops and recording of it for adjustment of dry grains, all these steps are performed by trained field staff. The cost of crop production is estimated by the scheme of Cost of Cultivation Studies (CCS) conducted by DESAg and operated by agricultural universities. The livestock population data are collected through a quinquennial Indian Livestock Census (ILC) conducted by State Animal Husbandry Departments. The data on Livestock Products are taken from the annual Integrated Sample Survey (ISS) under the Department of Animal Husbandry and Dairying (DAHD) and NSSO livestock surveys. (Government of India, 2018)

Figure 3: All India Foodgrains Yield (Kg/Hectare) from 1950-51 to 2016-17 


\section{Sanrachna}

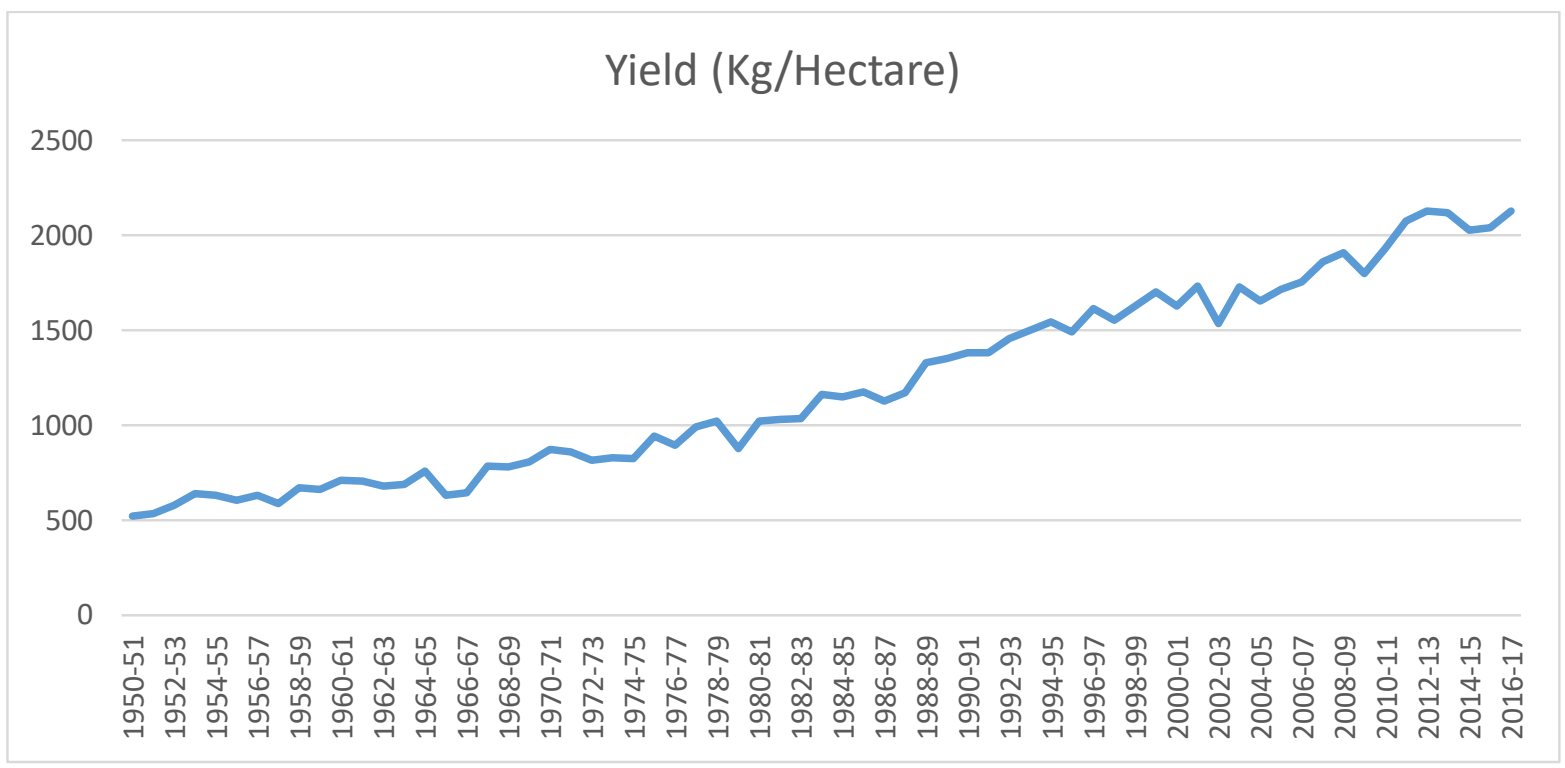

Source: Agricultural Statistics at a Glance 2018

\subsection{Release of Crop Estimates}

For policy purposes related to pricing, marketing, import/export and distribution etc., the government require the advance estimates of production of crops. However, farming activities which includes sowing, harvesting, and threshing etc., are performed during the season i.e. from July to June. Thus the advance estimates at four separate point of time in a year have been evolved to meet the requirement. The first advance estimates are prepared in September every year in which area and production of Kharif crops are estimated. The second advance estimates are prepared in January every year. Under second advance estimates, the first assessment of Kharif crops get revised and for the rabi crops, the first assessment is prepared. The third advance estimates are prepared at the end of March or at the beginning of April every year. Under third advance estimates, the advance estimates of both Kharif and rabi crops are validated with the latest information available through various related authorities. The fourth advance estimates are prepared in June/July every year. The third advance estimates for both Kharif and rabi crops get revised in fourth advance estimates. It also helps in SASAs to provide better estimates for both crops since by end of the May mostly rabi crops get harvested. The final estimates released in December/January.

\section{Agriculture in NAS}


Sanrachna

To know the contribution of the agriculture sector in NAS, it is important to understand what component of the agriculture sector compiled in the NAS and how it is measured. The agriculture and allied industry consist of four sectors: crop sector, livestock sector, forestry sector, and fishing and aquaculture sector. However, the agriculture and allied activities in the National Accounts Statistics, include the agriculture proper, livestock \& its products and operation of irrigation (shown in table 2 in the appendix). The operation of irrigation includes the supply of water through various government channels to the agriculturists.

Figure 4: GVA by Agriculture \& Allied Sector at Current price and Constant price (201112)

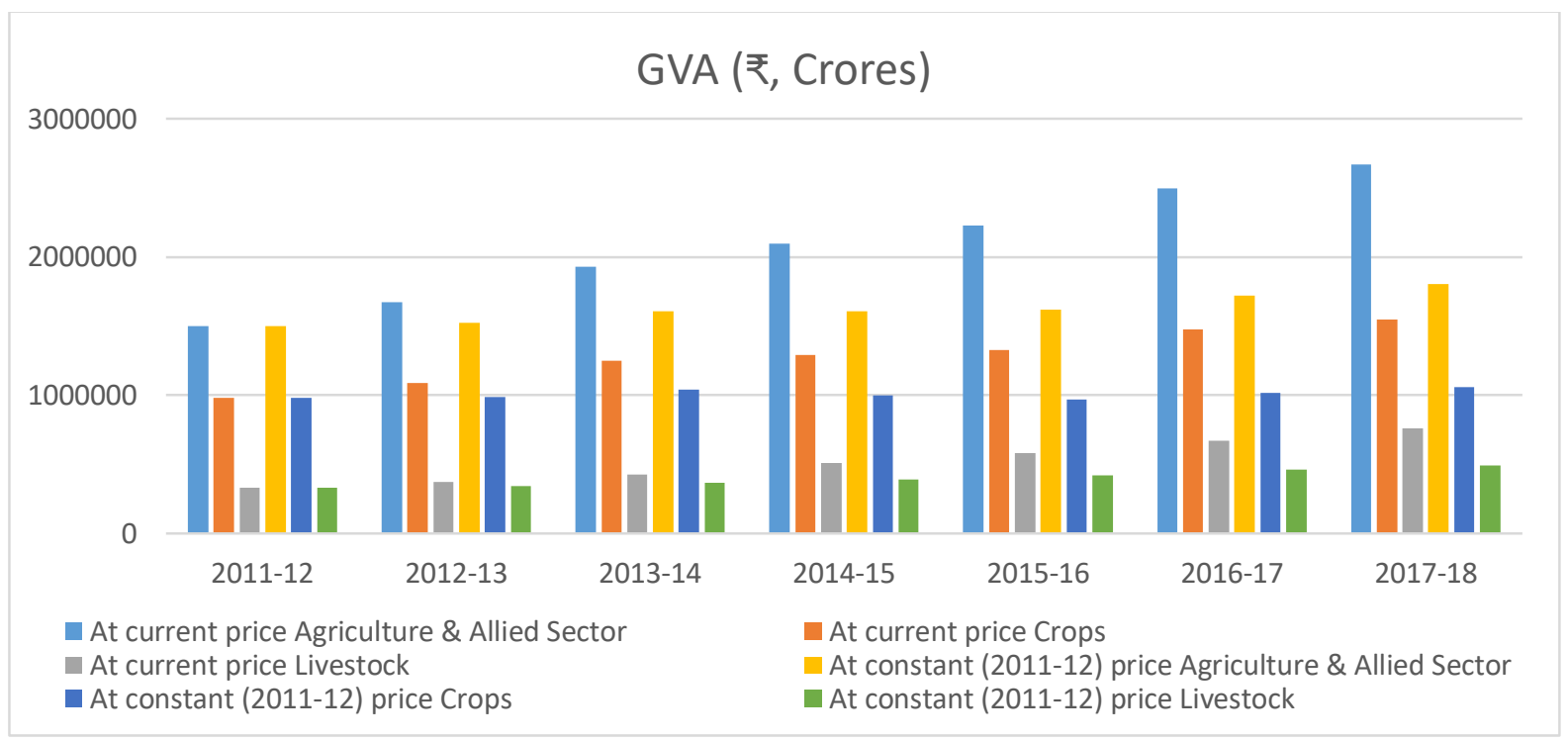

Source: NITI Aayog, 2019

The GVA for agricultural activity is estimated by using the production method. However, the operation of an irrigation system is estimated by using the income approach. Under this, the gross factor income generated through irrigation services is estimated. However, the irrigation system operated by farmers is not taken into account as its value is automatically counted in the value of crops and the expenditure in the overall input costs. Often agriculture and livestock activities go together as the inputs are generally common to both livestock and agriculture sector thus the value-added estimates were prepared for combine activity but the value of output is estimated separately. However, for the 2011-12 series, the GVA of the crop sector and livestock sector are calculated separately by bifurcating the common inputs. Here in estimating the GDP, the output for agriculture and allied sectors are considered to be crops and 
Sanrachna

livestock products. The sources of output and inputs for agriculture and livestock sector are given in tables 4 and 5 in appendix

Table 1: The Output of Agriculture \& Allied Sector, 2017-18 (₹, crores)

\begin{tabular}{|l|l|l|l|l|l|}
\hline \multicolumn{2}{|l|}{ At Current Price } & At Constant Price (2011-12) \\
\hline Output & $\begin{array}{l}\text { Intermediate } \\
\text { consumption }\end{array}$ & GVA & Output & $\begin{array}{l}\text { Intermediate } \\
\text { consumption }\end{array}$ & GVA \\
\hline 3416829 & 746683 & 2670147 & 2342177 & 539139 & 1803039 \\
\hline
\end{tabular}

Source: National Accounts Statistics, 2019

\subsection{Input of Agriculture and Livestock Sector}

The input of the agriculture and livestock sector consists seeds, organic manure, chemical fertilizers, feed of livestock, market charges, diesel oil, irrigation charges, electricity supplied to the agriculture sector, repairs and maintenance, FISIM, and pesticides \& Insecticides. To estimate the value of seeds, the quantity of seeds is computed with farm harvest price for irrigated and unirrigated $\operatorname{areas}^{2}$. The seed rate $(\mathrm{kg} / \mathrm{hectare})$ estimates are based on the CCS. The estimation of livestock feed is derived using the consumption approach. The livestock feed consists of Roughages (cane trash, fodder, grass and 95\% of the value of stalks and straw) and Concentrates. To differentiate the livestock feed between crop sector and livestock sector, it is assumed that livestock feed used for crop production would be feed consumed by (Adult Male) Buffalo and Cattle. The value of livestock feed for the livestock sector is derived from subtracting the livestock feed used for crop production from the total feed of livestock. In FISIM, the proportion of bank charges or FISIM for the agriculture sector to the GVA of this sector is taken.

Table 2: Output \& Value Added from Crop Sector and Irrigation, 2017-18 (₹, crores)

\begin{tabular}{|l|l|l|}
\hline \multicolumn{2}{|l|}{ At Current Price } & At Constant Price (2011-12) \\
\hline Crop Sector & 1888953 & 1321941 \\
\hline Value of Output & 315872 & 240315 \\
\hline Input & 41069 & 29499 \\
\hline Seed & 37471 & 24061 \\
\hline organic manure & &
\end{tabular}

${ }^{2}$ For evaluating the value of improved/hybrid variety of seeds, state-wise seed replacement rate i.e. rate at which ordinary seeds are replaced with hybrid seeds, is used. 


\section{Sanrachna}

\begin{tabular}{|l|l|l|}
\hline chemical fertilisers & 52306 & 43403 \\
\hline $\begin{array}{l}\text { current repairs, maintenance of fixed } \\
\text { assets \& other operational costs }\end{array}$ & 16865 & 14311 \\
\hline feed of livestock & 47141 & 30048 \\
\hline irrigation charges & 4718 & 3929 \\
\hline market charges & 60824 & 42567 \\
\hline electricity & 22247 & 13518 \\
\hline pesticides \& insecticides & 2076 & 2227 \\
\hline diesel oil & 31155 & 36753 \\
\hline FISIM & 68927 & 61269 \\
\hline Gross Value Added & 1504154 & 1020358 \\
\hline Irrigation & & \\
\hline value of output & 51655 & 41717 \\
\hline Input & 9001 & 5516 \\
\hline Gross Value Added & 42654 & 36202 \\
\hline
\end{tabular}

Source: National Accounts Statistics, 2019

Table 2.1: Output \& Value Added from Livestock Sector, 2017-18 (₹, crores)

\begin{tabular}{|l|l|l|}
\hline & At Current Price & At Constant Price (2011-12) \\
\hline Value of Output & 1043656 & 677960 \\
\hline Input & 284688 & 183794 \\
\hline feed of livestock & 277994 & 178523 \\
\hline $\begin{array}{l}\text { current repairs, maintenance of fixed } \\
\text { assets \& other operational costs }\end{array}$ & 6577 & 5154 \\
\hline market charges & 117 & 117 \\
\hline FISIM & 551 & 490 \\
\hline Gross Value Added & 758417 & 493676 \\
\hline
\end{tabular}

Source: National Accounts Statistics, 2019

\subsection{Capital formation and Factor Income in Agriculture}

Fixed Capital formation in agriculture is consist of assets (i) expenditure on construction and (ii) acquisition of machinery and equipment (ME) by various institutional sectors. The ME is estimated by using the data from the Annual Survey of Industry (ASI) and IOTT ratios for agricultural implements, whereas AIDIS information is used for construction estimates. While in estimating CIS, the change in the population of livestock except for the proportion which is used as capital assets (breeding, dairying and as draught animals) is considered. The estimates 


\section{Sanrachna}

of capital formation in agriculture are separately prepared for the public, private corporate, and the household sectors. The estimates of capital stock are obtained through the information of capital formation by using the perpetual inventory method (PIM).

Table 3: GFCF, CIS, and GCF by the Agriculture \& Allied Sector, 2011-12 (₹ Crore)

\begin{tabular}{|c|c|c|c|}
\hline Industry & 2004-05 series & 2011-12 series & \% Difference \\
\hline \multicolumn{4}{|l|}{ GFCF } \\
\hline $\begin{array}{l}\text { Agriculture \& Allied } \\
\text { sector }\end{array}$ & 241178 & 267687 & 11.0 \\
\hline Crops & \multirow[t]{2}{*}{223118} & 233756 & \multirow[t]{2}{*}{13.8} \\
\hline Livestock & & 20197 & \\
\hline \multicolumn{3}{|l|}{ CIS } & \\
\hline $\begin{array}{l}\text { Agriculture \& Allied } \\
\text { Sector }\end{array}$ & 10527 & 7632 & -27.5 \\
\hline Crops & \multirow[t]{2}{*}{10166} & 1614 & \multirow[t]{2}{*}{-29.0} \\
\hline Livestock & & 5602 & \\
\hline \multicolumn{4}{|l|}{ GCF } \\
\hline $\begin{array}{l}\text { Agriculture \& Allied } \\
\text { Sector }\end{array}$ & 251705 & 275319 & 9.4 \\
\hline Crops & \multirow[t]{2}{*}{233284} & 235370 & \multirow[t]{2}{*}{12.0} \\
\hline Livestock & & 25800 & \\
\hline
\end{tabular}

Source: Changes in Methodology and Data Sources in the New Series of National Accounts, 2015

For estimating factor incomes for the agriculture sector, the net value added classified in the public sector and private sector. The public sector consists of Government irrigation system and private sector consist of plantation crops, crops excluding plantation crops, and animal husbandry. The estimates of factor income and property income for plantation crops are taken from Company Finance Studies conducted by RBI and annual reports of these boards. While estimates of factor income for crop production except plantation and animal husbandry are derived from CCS and AIDIS report.

Table 4: GCF by Agriculture \& Allied Sector, 2017-18, (₹ crores) 
Sanrachna

\begin{tabular}{|c|c|c|c|c|r|}
\hline $\begin{array}{l}\text { Agriculture \& } \\
\text { Allied Sector }\end{array}$ & Crops & Livestock & $\begin{array}{l}\text { Agriculture \& } \\
\text { Allied Sector }\end{array}$ & Crops & Livestock \\
\hline 366101 & 300863 & 37603 & 273755 & 222168 & 27261 \\
\hline
\end{tabular}

Source: National Accounts Statistics, 2019

\section{Challenges of Agriculture Database}

Currently, the compilation centre for the data is the state and hence, the intra-state variations between various aggregates remain unknown. For making concrete planning and policy, agricultural statistics at the regional level becomes crucial. To ensure the accuracy of it, the related data must be collected by the district-level agencies. However, the data on production and prices at the district-level is not available for all the crops. The absence of these data at district-level does not give accurate estimates of the value of output. Generally, the prices estimates are based on wholesale price prevailing in primary market centres during the peak market season but in some case, it is observed that some farmers have the capacity to retain agricultural produce till they get a high price for it. This cause under-estimation of income but the data of prices related to the first point of the transaction, at which income accrued to producers, are not available. Moreover, estimates for price-controlled commodities are published only controlled price statistics and not the open market price. But to analyse the trend in the market, the open market price is considered as great importance. In addition to this, for comparability between states, there is no system for auditing the prices data.

\subsection{Methodological Challenges}

In NAS, sometimes the change in the base year and up-gradation of methodology also leads to an underestimation of the agriculture sector. Such as the gross state domestic product at two different base price: at 1980-81 price for 1980-81 through 1997-98 and at 1993-94 price for 1993-94 through 2003-04. Apart from prices, these two series are different in terms of improvement in methodology and inclusion of various activities across sectors. The changes in database and sectoral composition makes the inter-temporal comparability difficult. Thus, the estimates are difficult to measure if the revision is performed while converting the old series into a new series. Similarly, for 2004-05 price series the capital formation for crop and livestock sector measured combined but in 2011-12 price series this estimates for both sectors measured 
separately which creates the problem of incomparability. However, the comparability problem tends to decline with the methodology suggested by UN SNA to converge it. (Agarwal, 2012)

The other problem is in the measurement of capital formation where the private investment by small farmers is usually not registered. Also, many researchers point out that 'capital formation in agriculture', is not a good indicator of measuring the growth of agriculture in NAS. It says that 'capital formation for agriculture' is more pertinent for understanding the development of agriculture as it explains the impact on agriculture more directly and meaningfully. (Kulshrestha, 2004)

In agriculture, estimating value addition at different stages is quite a complex process. Like many women in the families who engage in the processing activity of raw produce, often mixed their household job with other processing activities. Thus, detailed information on agricultural produce value at various stages is needed. On the other hand, disguised unemployment is widespread in agriculture, those who are not engaged productively are often included in the workforce making it overestimate. Similarly, there is no accurate data of those workers who pursue other activities while making a part-time contribution to agriculture. Hence, to check the reliability of labour data, detailed time use surveys is necessary.

\subsection{Data Gaps and Quality Issues}

There are many significant data gaps found in the agricultural system. The estimates of yield rates for minor crops (crops are shown in table 3 in appendix) are available after a considerable time lag and also, not based on scientific methods. For estimation of horticulture crops, DES scheme covers only 11 states with only 7 fruits and 7 vegetables and spice crops. Also, the methodology used by the National Horticulture Board (NHB) for estimation is not cleared. The major data gaps in agriculture are related to the separate data for many emerging new commercial crops such as mushroom and floriculture, high valued minor crops, other kinds of plants and medicinal herbs. These relatively new areas of cultivation and other ancillary activities such as cut flowers, dried flowers and other parts of plants, due to the poor database, may not be computed in the estimation of GDP. (Kulshreshtha, 2004) 
Besides all this, the number of crops covered in CCS for each state is very few and the sample size is also about 10,000 which is too less to give reliable information. Further, the results of these studies release at the time lag of 3 years which delays the process of computation. The other issue with CCS is that it is not conducted in all states hence, the norms of neighbouring states is applied to these states which creates a problem as states have different soil and farm conditions. For unspecified crops only area estimates are available on an annual basis hence, the value of output estimates depends on related major crops group. Over this, the crop production in foryard/backward is only estimated for rural areas and that too at the lag of 10 years. Moreover, the gur production estimates are not directly available and it is assumed that state-wise $9-10 \%$ of sugarcane quantity is retained for gur making ${ }^{3}$. (Agarwal, 2012) For estimating the factor incomes, details data are not available particular for the case of the livestock sector.

The system of estimating the value of inputs also has some drawbacks. Repairs and maintenance estimates for the value of inputs are available only at the lag of 10 years. For major and minor irrigation project, there is a flaw in capturing the real-time inflow of water and its utilisation. Also, there is a large variation in irrigated areas statistics published by different agencies. Statistics on the input of agriculture such as fertiliser is also not available in time and often incomplete. The mechanism of collecting and compiling the data on pesticides does not have fully developed statistical support hence, not have long-term effective use. The data on agricultural machinery and implements is provided by only manufacturers and includes tractors and power tillers only.

In the case of livestock, there is a huge time lag in the availability of the data. The livestock population data are available at the gap of five years through ILC. The yield rates of livestock products are also not regularly available and along with that, there is no uniformity between states related to the reference period. Besides, the milk estimation from the animals other than a cow, buffalo, and goat is not available, hence, not included in the estimation of GDP. In

\footnotetext{
${ }^{3}$ The gur production estimates are assumed to be total sugarcane production minus sugarcane used for chewing, seed, crushed by factory and khandsari.
} 
Sanrachna

addition to this, the conversion of milk to milk-products such as desi ghee, butter, khoa, cream etc., are not available for outside the domestic consumption. Similarly, the yield rates estimate for meat products and by-products are not based on any scientific techniques. There are also huge data gaps in terms of no reliable annual estimates of livestock population. As there is a lack of annual data on the death of the animals due to natural calamities and animal slaughtered at unregistered slaughterhouse plus ILC is not conducted at the same time by all states. In addition to this, producers prices are generally not available for livestock products.

Along with data gaps, bad quality of data is also a major concern. This bad quality reflects in timely completion of area enumeration as per the findings of the scheme of Improvement of Crop Statistics (ICS) taken by NSSO. As per the findings it has observed that the timely completion of the area at country level is less than $40 \%$ for autumn and less than $60 \%$ in winter, and summer. Also, the same state-level data is alarmingly unsatisfactory for some states (Kulshreshtha, 2004). Besides, the nine classifications of land use do not provide information like social forestry, marshy and waterlogged land, built-up land etc. These wide classifications also create a problem for patwari as in most cases they are unable to identify the characteristics of various categories. The land records maintained by patwari does not computerized and also remain the same since the mid-1950s. Thus, there is a high chance of incorrect data submitted manually. It also does not provide the cropping practices applied by households. Besides, it causes a delay in the submission of area reports which further delay the whole estimation process. The lack of correct area estimates leads to incorrect yield estimates through CCE, also non-availability of equipment to conduct CCE weakening the agricultural statistics. The problem also occurs because of the different political and social condition of states which makes surveys in many states difficult. The gap and poor database of input and output estimates of the agriculture and livestock sector may lead to the false input-output ratio which further gives a false narration of agricultural growth and its share in GDP.

\section{Conclusion}

Agriculture has a significant role in the Indian economy. Hence, the statistics and data related to the agriculture sector are very crucial for policy planners. However, due to poor agricultural database, the actual contribution of this sector is underrated. There are a lot of discrepancies in agriculture database which needs to be corrected for better policy planning and to accurately 
measure national accounts. India does not have any regional statistical agency which collects the data at the local level. Along with this, there is no systematic or time-bound survey for agriculture database. India needs to expand its statistical agency at the deep root level and try to seek a modern way to make these data more accurately to minimise the human error. For that, we need a strong digital system for tracking and maintaining the database. We also, do not have any Central agency for agricultural prices to cross-verify the prices data maintained by States. Also, there is an urgent need to standardize the concept related to livestock yield. For correct estimation of the value of agriculture and livestock products, the prices for many items and from many markets need to be collected. With passing time and growing technology, a relatively new area of cultivation has emerged which needs to be measured in national accounts. Lastly, we also need to implement the recommendation by expert committees on an urgent basis to improvise our national accounting system and have to place agricultural statistical system at priority. 
Sanrachna

\section{References}

Agarwal, A. and Mitra, A. (2012), Agriculture and Its Integration with National Accounts Statistics: The Indian Case, Social Science Research Network, Accessed from https://papers.ssrn.com/sol3/papers.cfm?abstract id=2091496

GOVERNMENT OF INDIA, Economic Survey, Ministry of Finance, 2019-20, Accessed from https://www.indiabudget.gov.in/economicsurvey/doc/vol2chapter/echap07_vol2.pdf

GOVERNMENT OF INDIA, Agricultural Statistics, Central Statistical Organisation, Ministry of Statistics and Programme Implementation, Accessed from http://www.mospi.gov.in/4agricultural-statistics

GOVERNMENT OF INDIA, Agricultural Statistics at a Glance 2018, Directorate of Economics and Statistics, Department of Agriculture and Cooperation, Ministry of Agriculture \& Farmers Welfare, 2018, Accessed from http://agricoop.gov.in/sites/default/files/agristatglance2018.pdf

GOVERNMENT OF INDIA, National Accounts Statistics - Sources and Methods 2012, Central Statistical Organisation, Ministry of Statistics and Programme Implementation, 2012, Accessed from http://mospi.nic.in/sites/default/files/publication_reports/sources_method_2012\%20(1).pdf

GOVERNMENT OF INDIA, Changes in Methodology and Data Sources in the New Series of National Accounts, Ministry of Statistics and Programme Implementation, 2015, Accessed from

http://www.mospi.gov.in/sites/default/files/press_releases_statements/Changes\%20in\%20Methodolog y\%20NS\%202011-12\%20June\%202015.pdf

GOVERNMENT OF INDIA, National Accounts Statistics, Ministry of Statistics and Programme Implementation, 2020, Accessed from http://www.mospi.gov.in/13-national-accounts$\underline{\text { statistics\# }}$

GOVERNMENT OF INDIA, National Accounts Statistics 2019, Ministry of Statistics and Programme Implementation, 2020, Accessed from c

Kulshreshtha, A.C. (2004). Agricultural Statistics - Data Availability, Requirements and Gaps from the Perspective of National Accounts Statistics, Journal of the Indian Society of Agricultural Statistics. 57 (Special Volume), pp. 345-368, Accessed from http://isas.org.in/jsp/volume/vol57/issueSV/A.C.Kulshreshtha.pdf

NITI Aayog, Planning Commission, Government of India, 2019, Accessed from https://niti.gov.in/planningcommission.gov.in/docs/data/datatable/index.php?data=datatab 


\section{Sanrachna}

\section{Appendix}

Table 1: Land Use Categories followed by States

\begin{tabular}{|l|l|}
\hline Categories of Land Use Data & States/UTs that follow the Categories \\
\hline Temporarily settled states & $\begin{array}{l}\text { Andhra Pradesh, Assam (excluding hilly districts), Bihar, } \\
\text { Chhattisgarh, Gujarat, Haryana, Himachal Pradesh, Jammu \& } \\
\text { Kashmir, Jharkhand, Karnataka, Madhya Pradesh, Maharashtra, } \\
\text { Punjab, Rajasthan, Tamil Nadu, Telangana, Uttar Pradesh, } \\
\text { Uttarakhand, UTs of Chandigarh, Delhi, Dadra \& Nagar Haveli } \\
\text { and Puducherry }\end{array}$ \\
\hline Permanently settled states & $\begin{array}{l}\text { Kerala, Odisha and West Bengal, Arunachal Pradesh, Nagaland, } \\
\text { Sikkim and Tripura. }\end{array}$ \\
\hline Third Category & $\begin{array}{l}\text { Hilly districts of Assam, Meghalaya, Mizoram, Manipur, Goa, } \\
\text { UTs of Andaman \& Nicobar Islands, Daman \& Diu and } \\
\text { Lakshadweep }\end{array}$ \\
\hline
\end{tabular}

Source: Agricultural Statistics at a Glance 2018

Table 2: Activities included in Agriculture Proper and Livestock Sector

\begin{tabular}{|l|l|}
\hline Agriculture Proper & Livestock Sector \\
\hline vegetables & \\
\hline Management of tea, coffee and rubber plantation & Slaughtering, preparation and dressing of meat \\
\hline Agricultural and horticultural services on a fee or & Eggs \\
\cline { 2 - 2 } contract basis & Raw wool \\
\hline Ancillary activities of cultivators such as gur & Dung \\
\cline { 2 - 2 } making, yielding rental income from the farm, & Silk Worm cocoons and honey \\
\cline { 2 - 2 } transporting own produce to market & Production of raw hides, skins, and milk \\
\hline
\end{tabular}

Source: National Accounts Statistics - Sources and Methods, 2012

Table 3: Crops comes under Major Crops, Minor Crops, and Miscellaneous Crop

\begin{tabular}{|c|c|c|}
\hline Major Crops & Minor Crops & Unspecified and miscellaneous crop \\
\hline Paddy & Potato & Other Cereals \\
\hline Wheat & Onion & Other Sugars (excluding Palmyra) \\
\hline Jowar & Banana & Other Oilseeds (excluding Taramira) \\
\hline Bajra & Tapioca & Other Fibres \\
\hline
\end{tabular}




\section{Sanrachna}

\begin{tabular}{|c|c|c|}
\hline Maize & Sweet Potato & Other Drugs and Narcotics \\
\hline Ragi & Pepper & Other Condiments and Spices \\
\hline Barley & Ginger & Other Fruits \\
\hline Small millets & Garlic & Tobacco Stem \\
\hline Gram & Chillies & Toddy \\
\hline Tur & Turmeric & Fodder \\
\hline Groundnut & Arecanut & Mulberry \\
\hline Sesamum & Coriander & \\
\hline Rapeseed and Mustard & Cardamom & \\
\hline Linseed & Sun Hemp & Miscellaneous Food and Non-Food crops \\
\hline Castor Seed & Tobacco & \\
\hline Safflower & Guar Seed & \\
\hline Niger Seed & Coconut & \\
\hline Soybean & & \\
\hline Sunflower & & \\
\hline Cotton & & \\
\hline Jute & & \\
\hline Mesta and Sugarcane & & \\
\hline Source Dirctorate & & \\
\hline
\end{tabular}

Source: Directorate of Economics \& Statistics, Department of Agriculture and Cooperation

Table 4: Value of output, inputs of crops and their data sources

\begin{tabular}{|c|c|}
\hline Crops Groups & Sources of Data \\
\hline \multicolumn{2}{|c|}{ Value of Output } \\
\hline Major Crops & $\begin{array}{l}\text { Production: DESAg } \\
\text { Prices: State DESs }\end{array}$ \\
\hline Minor Crops & $\begin{array}{l}\text { Production: Horticulture Statistics Division (DAC, } \\
\text { M/o Agriculture) and State DESs } \\
\text { Price: State DESs }\end{array}$ \\
\hline $\begin{array}{l}\text { Commercial Crops: } \\
\text { Tea } \\
\text { Coffee } \\
\text { Rubber } \\
\text { Cashew Nuts and Cocoa } \\
\text { Horticulture Crops } \\
\text { Opium }\end{array}$ & $\begin{array}{l}\text { Production: } \\
\text { Tea Board } \\
\text { Coffee Board } \\
\text { Rubber Board } \\
\text { Directorate of Cashew and Cocoa Development } \\
\text { Board } \\
\text { Horticulture Statistics Division } \\
\text { Prices: State DESs } \\
\text { Production and Price: Central Bureau of Narcotics }\end{array}$ \\
\hline $\begin{array}{l}\text { Miscellaneous crops and Other Fruits and } \\
\text { Vegetables }\end{array}$ & $\begin{array}{l}\text { Area: LUS from DESAg/ State DESs } \\
\text { Production: Horticulture Statistics Division } \\
\text { Price: State DESs }\end{array}$ \\
\hline $\begin{array}{l}\text { Other Products: } \\
\text { Gur } \\
\text { Palmyra } \\
\text { Bagasse }\end{array}$ & $\begin{array}{l}\text { Production and Seed Rates: DESAg } \\
\text { Quantity of sugar cane crushed by factories: } \\
\text { Directorate of Sugar, Department of Food and } \\
\text { Public Distribution, Ministry of Consumer Affairs } \\
\text { Quantity of sugarcane used in manufacture of } \\
\text { khandsari: ASI \& NSS Survey of manufacturing } \\
\text { enterprises } \\
\text { Prices: State DESs }\end{array}$ \\
\hline
\end{tabular}




\section{Sanrachna}

\begin{tabular}{|c|c|}
\hline & and (iii) Production and Price: State DESs \\
\hline \multicolumn{2}{|l|}{ Inputs (Crop Sector) } \\
\hline Seeds & $\begin{array}{l}\text { Seed rate, seed replacement rate: CCS from DESAg } \\
\text { Area and Price: State DESs } \\
\text { Seed price of paddy, sugarcane, and potato: State } \\
\text { DESs } \\
\text { Value per Hectare (VPH) of other cereals, spices, } \\
\text { coconut, miscellaneous food crops: Study conducted } \\
\text { by Directorate of Marketing Inspection (DMI), M.o } \\
\text { Agriculture } \\
\text { VPH for Miscellaneous Non-Food crops: Benchmark } \\
\text { study conducted by State DESs }\end{array}$ \\
\hline Pesticides & $\begin{array}{l}\text { Consumption and Price: Directorate of Plant } \\
\text { Protection, Quarantine \& Storage }\end{array}$ \\
\hline Repair \& Maintenance for crop sector & $\begin{array}{l}\text { Average cost of repair and maintenance on orchards } \\
\& \text { plantation, wells \& irrigation, agricultural } \\
\text { machinery, and transport equipment: AIDIS }\end{array}$ \\
\hline Electricity & $\begin{array}{l}\text { Consumption of electricity for agriculture purpose } \\
\text { and price: Central Electricity Authority }\end{array}$ \\
\hline Diesel Oil & $\begin{array}{l}\text { Number of tractors: Agriculture Research Data Book, } \\
\text { ICAR } \\
\text { Number of diesel engines: ILC } \\
\text { Consumption of diesel oil per diesel engine and per } \\
\text { tractor: CCS from DESAg }\end{array}$ \\
\hline Chemical Fertilisers & $\begin{array}{l}\text { Consumption and Price: Fertiliser Association of } \\
\text { India }\end{array}$ \\
\hline Irrigation Charges & $\begin{array}{l}\text { Gross irrigated area: State DESs } \\
\text { Receipts of Government from sale of water: State } \\
\text { Government Budget }\end{array}$ \\
\hline Market Charges for Crops & $\begin{array}{l}\text { Market Margin Study conducted by the DES, M/o } \\
\text { Agriculture }\end{array}$ \\
\hline $\begin{array}{l}\text { Operation of Government Irrigation } \\
\text { System }\end{array}$ & Central \& State Government Budget documents \\
\hline
\end{tabular}

Source: Changes in Methodology and Data Sources in the New Series of National Accounts, 2015

Table 5: Value of output, input of Livestock and Livestock Products and their data source

\begin{tabular}{|l|l|l|}
\hline \multicolumn{1}{|c|}{ Categories } & \multicolumn{1}{c|}{ Item } & \multicolumn{1}{c|}{ Sources of Data } \\
\hline \multicolumn{2}{|c|}{ Value of Output } \\
$\begin{array}{l}\text { Milk, Eggs, and } \\
\text { Wool }\end{array}$ & $\begin{array}{l}\text { Milk (Cattle, Buffalo, and Goat), Eggs, } \\
\text { and Wools }\end{array}$ & $\begin{array}{l}\text { Production: ISS, (DAHD); DESs } \\
\text { for Camel milk } \\
\text { Prices: State DESs }\end{array}$ \\
\hline
\end{tabular}




\section{Sanrachna}

\begin{tabular}{|c|c|c|}
\hline $\begin{array}{l}\text { Meat Group } \\
\text { (i) Meat } \\
\text { (ii) Meat Products } \\
\text { (iii) By-products }\end{array}$ & $\begin{array}{l}\text { Beef, Mutton, Pork, Poultry Meat and } \\
\text { glands } \\
\text { Fats, heads and legs of slaughtered } \\
\text { animals } \\
\text { Hides, skin, guts, blood, bones, horns, } \\
\text { hoofs, tail stump, useless meat and } \\
\text { oesophagus, camel/goat hair }\end{array}$ & $\begin{array}{l}\text { (i) and (ii) } \\
\text { Poultry Population: ILC from } \\
\text { DAHD Production: ISS from } \\
\text { DAHD and State DESs, } \\
\text { Prices: State DES } \\
\text { (iii) Population: ILC from DAHD } \\
\text { Yield rates for goat hair: DMI } \\
\text { reports } \\
\text { Prices: State DESs }\end{array}$ \\
\hline Dung & Dung Fuel and Dung Manure & $\begin{array}{l}\text { Population: ILC from DAHD } \\
\text { Prices, Utilization rate and } \\
\text { Evacuation rate: State DESs }\end{array}$ \\
\hline $\begin{array}{l}\text { Silkworm, Cocoons } \\
\text { and Honey }\end{array}$ & $\begin{array}{l}\text { Silkworm (Mulberry, Tussar, Ericot } \\
\text { and Muga), Honey, and Bee Wax }\end{array}$ & $\begin{array}{l}\text { Production and Price of Silk: } \\
\text { Central Silk Board } \\
\text { Production and Price of Honey: } \\
\text { KVIC } \\
\text { Production and Price of Bee Wax: } \\
\text { State DESs }\end{array}$ \\
\hline Increment in Stock & $\begin{array}{l}\text { Increment in livestock of all categories } \\
\text { of all animals }\end{array}$ & $\begin{array}{l}\text { Population: ILC from DAHD } \\
\text { Prices: State DES }\end{array}$ \\
\hline \multicolumn{3}{|l|}{ Inputs } \\
\hline $\begin{array}{l}\text { Repairs and } \\
\text { Maintenance for } \\
\text { Livestock and } \\
\text { Operational Cost }\end{array}$ & $\begin{array}{l}\text { Barns, Animals Sheds and Other } \\
\text { miscellaneous }\end{array}$ & $\begin{array}{l}\text { Average Cost of Repair and } \\
\text { Maintenance: AIDIS }\end{array}$ \\
\hline $\begin{array}{l}\text { Market Charges for } \\
\text { Livestock }\end{array}$ & & $\begin{array}{l}\text { Number of slaughtered animals: } \\
\text { ISS from DAHD } \\
\text { Municipal Charges per slaughtered } \\
\text { animals: State DESs }\end{array}$ \\
\hline Livestock Feed & & $\begin{array}{l}\text { Age-wise Species-wise } \\
\text { Population: ILF from DAHD } \\
\text { State-wise average price for Dry } \\
\text { Fodder, Green Fodder, and } \\
\text { Concentrates: CCS from DESAg }\end{array}$ \\
\hline
\end{tabular}

Source: Changes in Methodology and Data Sources in the New Series of National Accounts, 2015 